\title{
SPATIOTEMPORAL VARIATION AND CLIMATE CHANGE IMPACT ON RADIAL GROWTH OF CHIR PINE (PINUS ROXBURGHII) IN A SUBTROPICAL PINE FOREST IN PAKISTAN
}

\author{
IQBAL, S. ${ }^{1,2}-$ ZHA, T. S. ${ }^{1,2^{*}}-$ HAYAT, M. ${ }^{1,2}-$ KHAN, A. ${ }^{1,2}-$ ASHRAF, M. I. ${ }^{3}-$ AHMAD, B. ${ }^{4}-$ \\ SABA, N. U. ${ }^{5}-$ JAN, S. A. ${ }^{6}$ \\ ${ }^{I}$ Yanchi Research Station, School of Soil and Water Conservation, Beijing Forestry University, \\ Beijing 100083, China \\ ${ }^{2}$ Beijing Engineering Research Center of Soil and Water Conservation, Beijing Forestry \\ University, Beijing 100083, China \\ ${ }^{3}$ Department of Forestry, Arid Agriculture University, Murree Road, Rawalpindi 46300, \\ Pakistan \\ ${ }^{4}$ Institute of Agriculture Sciences and Forestry, University of Swat, Swat 19130, Pakistan \\ ${ }^{5}$ Faculty of Management Sciences, Riphah International University, Islamabad 44000, Pakistan \\ ${ }^{6}$ Forest Department, Government of Khyber, Pakhtunkhwa 18300, Pakistan \\ *Corresponding author \\ e-mail: tianshanzha@bjfu.edu.cn \\ (Received $18^{\text {th }}$ Dec 2019; accepted $6^{\text {th }}$ May 2020)
}

\begin{abstract}
Climate and topography both have a paramount role in defining tree species distribution. Global warming had increased the risk of climatic influences on the sustainability of subtropical pine forests. The radial growth $\left(\mathrm{R}_{\mathrm{g}}\right)$ allows to understand the long term variation in climate change-at different temporal and spatial scales. Here, we analyzed $144 \mathrm{R}_{\mathrm{g}}$ chronologies from 48 different sites in a subtropical pine forest in the Murree Hills of Pakistan. The results showed a strong non-linear relationship of annual precipitation (PPT) and annual mean air temperature $\left(T_{a}\right)$ with $\mathrm{R}_{\mathrm{g}}$. The results further indicated that previous and present summer precipitation imposed a positive impact on the $R_{g}(p<0.05)$. The previous summer $T_{a}$ showed a significant negative effect on $\mathrm{R}_{\mathrm{g}}$ while positively correlated during current July. The growth response analysis indicated that $\mathrm{R}_{\mathrm{g}}$ was often limited by variation in soil moisture associated with lower PPT and higher $T_{a}$. Moreover, the dependency of $R_{g}$ on PPT and $T_{a}$ varied along growing degree days (GDD $>5^{\circ} \mathrm{C}$ ), at different elevations. Our findings provide a remarkable evidence that the annual $\mathrm{R}_{\mathrm{g}}$ of $P$. roxburghii species appeared to be progressively limited by the effect of climate warming and varied spatially.
\end{abstract}

Keywords: air temperature, chronologies, growing degree days, Murree hills, precipitation

\section{Introduction}

An amplification in global earth surface temperature from 1880 to 2012, was observed at $0.85^{\circ} \mathrm{C}$ and the period from 1983 to 2012 was supposed to be the warmest thirty years since last fourteen centuries in the Northern latitudes (IPCC, 2014). How these climatic variations will dramatically affect terrestrial ecosystems is far from understood (Ma et al., 2012). Among these terrestrial ecosystems the major subtropical pine forest is predominantly distributed across indo-pacific south-western Himalayan region (Sheikh, 1993). The structure and function of forests are subject to be change by climate warming which also enhances the risk of severity in biotic and abiotic feedbacks i.e., wild fires droughts and insect outbreaks (Allen et al., 2010; Kasischke and Stocks, 2012; Price et 
al., 2013). Consequently, it is important to know the response of pine species to increasing climate change for accurate prediction of potential variations in subtropical pine forests.

Previous studies revealed that tree ring analysis provides a high resolution proxy to reform past climatic variation change (Esper et al., 2002; Cook et al., 2004; D'Arrigo et al., 2008), which helps in comprehend the association between tree growth and climatic variables (Hughes et al., 2010; Speer, 2010). Climatic parameters and tree growth depicts a linear relationship calibrated by traditional statistical functions and it remains consistent through time period (Jones et al., 2009; Tolwinski-Ward et al., 2011). In contrast, various studies have shown the presence of nonlinear and unstable relationships among tree growth and meteorological variables due to climate warming (Visser et al., 2010; Zhang and Wilmking, 2010). In particular, it has been revealed that pine species has shown a nonlinear relationship with climate variability (Lloyd et al., 2013; Saeed et al., 2016). The white spruce growth pattern showed lessened sensitivity to temperature in high altitudes (Porter and Pisaric, 2011; Lloyd et al., 2013), pointing out the divergence concern (D'Arrigo et al., 2008). The influence of climatic variables on tree ring growth might tend to vary along altitudinal gradients in climate and growth relationship for temporal changes. Therefore, long term temporal scale radial growth analysis is required to evidently state how tree-rings responds to environmental variables.

Many hydrometeorological factors influence the tree growth among which the available soil water contents and air temperature are the key variables (Schweingruber, 1996). Therefore, ring series of long-lived trees have ability to record long-term multiyear variation in climatic circumstances (Olano et al., 2012). Tree species may respond to climatic fluctuations in more complex ways due to the nature of complex physiology (Drew et al., 2013; Zang et al., 2014). Furthermore, temporal instability between tree growth and climate mediates their response patterns due to changes in constraining factors (Briffa et al., 2002; Leburgeois et al., 2012).

Climate enforces dual adversity on subsistence and evolution of many trees and shrubs i.e., erratic, unpredictable rain and associated extreme summer droughts (Valladares et al., 2014). The effect of drought varied along altitudinal gradient (Altman et al., 2017). Dramatic shifting behavior in forest ecosystems may not be happened only by direct response to climatic variations but usually associated to disturbances caused by climate change (Ghazoul et al., 2015). As climatic conditions varied continuously, the occurrence, impact and severity of disturbances on forest ecosystems are tend to increase globally (Flannigan et al., 2009; Turner, 2010; Seidl et al., 2014) and significantly modify the forest growth, structure, function, and successional trajectories (McCullough et al., 1998). Climatic change resulting variation in precipitation and temperature patterns, however such variations does not exhibit uniform pattern over entire year. Consequently, these limiting factors have relative importance in modulating the response of tree ring formation to climate change, caused predictions more difficult.

Many researches have documented the species-specific response of growth parameters to climatic variations, although they are subjected to same environmental conditions (Fekedulegn et al., 2003; Maxime and Hendrik, 2011). During the growing season, the growth of Oak was influenced by precipitation rates and not by temperature (Bednarz and Ptak, 1990) and suffered during water deficit conditions, but could not under plentiful water availability (Pilcher and Gray, 1982). In contrast, during the $20^{\text {th }}$ and $21^{\text {st }}$ centuries the positive radial growth of Beech species was observed with increasing temperature (Maxime and Hendrik, 2011) that was observed to be closely associated to scarce soil water condition (Bouriaud et al., 2004). Another studies have reported the strong 
possibility of Sycamore to largely decline in England, being more sensitive to water shortage during dry periods (Lemoine et al., 2001; Tissier et al., 2004). The responses of pine species to climate variation has been investigated in several Mediterranean and subtropical forest ecosystems. However, climate growth relationship of $P$. roxburghii in subtropical forests of Pakistan is still poorly understood.

In current study, to deeply insight on the species future persistence, we inspected the long-term continuing variation in the relationship stability between climate and growth of a subtropical Chir pine species ( $P$. roxburghii). This model plant, considered as a representative species of subtropical pine zone and being significant to its functioning (Sheikh, 1993). It is uncertain that how long-term variation in climatic drivers would affect the tree growth of mature $P$. roxburghii over the previous century.

This study provides a fundamental prospective to forecast the species performance and sustainability, under the consequences of global warming. In particular, we sought to understand what kind of relationship between climate and growth is revealed by $P$. roxburghii at long-term scale and meanwhile the correlation is stable or not. We examined a complex network of tree radial ring-increment chronologies from 48 pine locations in the subtropical pine forest along different elevations in Murree Hills, Pakistan. We hypothesized that the impact of climatic factors on radial growth $\left(\mathrm{R}_{\mathrm{g}}\right)$ of $P$. roxburghii might be varied along different elevations. The main objectives are: (1) to address the response of $\mathrm{R}_{\mathrm{g}}$ to climatic variations by computing the domino effect of traditional linear and nonlinear functions; and (2) to explore the potential temporal variation in $\mathrm{R}_{\mathrm{g}}$ along growing degree days (GDD), and different elevations.

\section{Methods}

\section{Study area}

The present study was conducted in Murree Hills of Pakistan $\left(33^{\circ} 47^{\prime} 15^{\prime \prime}\right.$ to $33^{\circ} 54^{\prime} 47^{\prime \prime} \mathrm{N}$ and from $73^{\circ} 16^{\prime} 54^{\prime \prime}$ to $73^{\circ} 29^{\prime} 18^{\prime \prime}$ E) in September 2015 (Fig. 1). The study area is dominant representative part of Subtropical Chir pine forest zone (Conifer specialist group, 1996) about $33 \mathrm{~km}$ North-East of Islamabad, the country's capital place. The elevation range from 939 to $1873 \mathrm{~m}$ a. s. 1 . Mean monthly air temperature of the region varies gently, $35^{\circ} \mathrm{C}$ to $50^{\circ} \mathrm{C}$ in summer and 0 to $2^{\circ} \mathrm{C}$ in winter. Mean monthly relative humidity is 70 percent or above (Sheikh, 1993). While mean annual rainfall is around $1140 \mathrm{~mm}$ per year (Nizami et al., 2012). The main soil type is loamy with a variable composition of clay, sand, and silt. The sedimentary rocks are in comprises of sandstones, limestone, shales, and marls (Sheikh, 1993). The area is naturally dominated by stand of Pinus roxburghii (chir), managed under Punjab shelterwood silviculture system. The other related tree species are Pinus wallichiana (kail), Pyrus pashia (batangi), and Quercus incana (rhin). The understory vegetation contains grasses and shrubs i.e., Dodonaea viscosa (sanatha), Carissa spinarum (granda), Myrsine africana (khukhal), Capparis decidua (karir), Adhatoda vasica (Bahekar), cannabis sativa (Bang) and Berberis lycium species (sumblu).

\section{Climate variables}

Meteorological data was continuously collected from the meteorological station situated near the study site from 1995-2015. The climate variables used in this study includes, monthly and annual total precipitation, monthly and annual mean temperature, 
and growing degree days $\left(\mathrm{GDD}>5^{\circ} \mathrm{C}\right)$. Continuous measurements of daily precipitation were monitored by tipping bucket rain gauges (TE525MM) and air temperature with HMP45C probes (HMP155A, Vaisala). The annual total precipitation was summed from the preceding September to the current August of each year. The climate of the region is subtropical, and is defined by hot, dry and long summer seasons while gentle mild, wet winters (CWB, 2006). In the study period, mean annual temperature varied considerably.
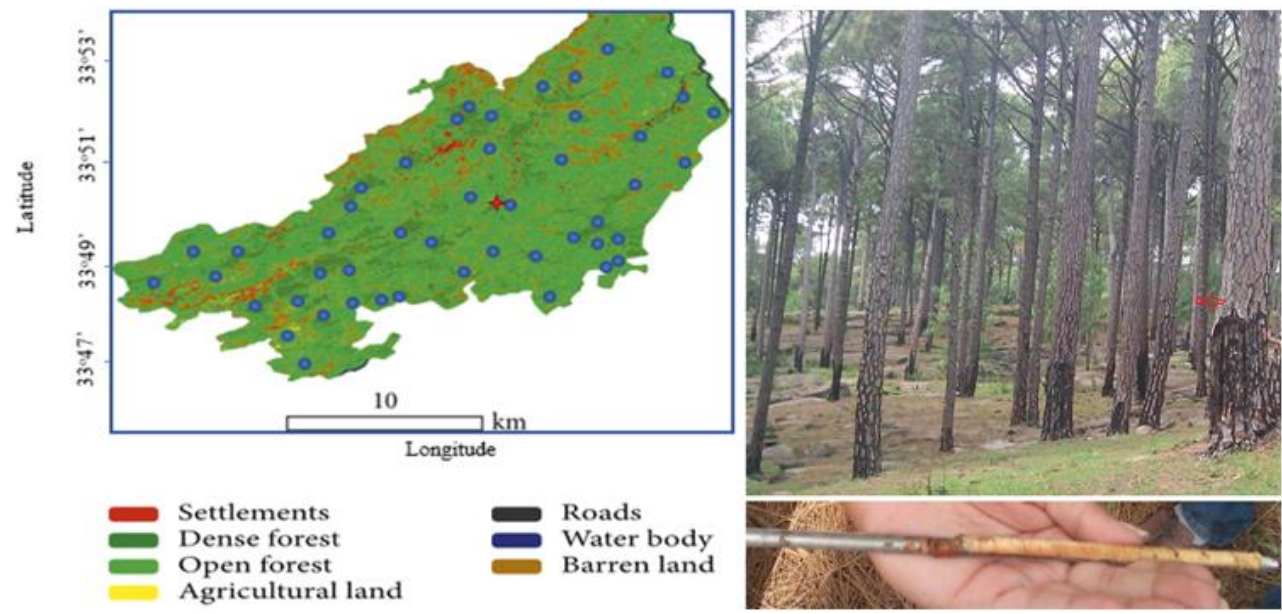

Figure 1. Location of study sites (48 P. roxburghii stand), sampled tree and fresh tree ring core of pinus roxburghii in Murree Hills Pakistan. Sampled tree is indicated by red arrow

\section{Radial growth data}

Trees were randomly sampled in the month of September during 2015 by following simple random sampling method. An average of three Pinus roxburghii trees were sampled from each site and 48 sites were sampled. The trees were cored with Pressler's increment borer (diameter $5 \mathrm{~mm}$ ) at $1.3 \mathrm{~m}$ above the tree base. Each of increment cores was carefully wrapped and stored in polythene bags. In the laboratory, the cores were pasted to wooden boards, and polished after drying with successively finer grits of sandpaper (up to 600 grid) to create clearly visible tree ring sequences. All tree ring chronologies were visually cross-dated at $1^{\text {st }}$, then tree-rings of each core were counted under a dissecting microscope with 20x magnification and also by using a Velmex tree ring computing system having $0.001 \mathrm{~mm}$ resolution. COFECHA was used in the verification process of visual cross dating (Holmes, 1983). In addition, in order to date the trees centuries, half centuries, and decades were marked with lead pencil. Ring-widths were measured by hand using the computer program Measure J2X, a measuring table, and a microscope with 40x magnification. Rings were measured for their seasonal (dark and light bands separately) and annual growth. The standardized ring chronologies more often contains variation like natural or biological persistence. Residual chronologies were developed and less frequency persistence were removed using an autoregressive (AR) model. It considered as a bi weight dynamic approach to reduce the effect of outliers. In total, 48 Chir pine simple, residual and mean ring-width chronologies were prepared using R software (Bunn, 2008). The prepared chronologies were finalized by rechecking the ring series showing potential errors and corrected if dating miscalculation was happened (Holmes, 1986). 


\section{Climate-growth analysis}

The relationship between climate and growth was evaluated by comparing tree ring chronologies to the climatic factors by using traditional nonlinear models and correlation analysis. Precipitation and air temperature of preceding to present growing season (May of previous year to August of current year) were tested. The significance of Pearson's correlation values was determined and the reliability of data was enhanced by bootstrapping method. The linear and nonlinear regression functions were fitted to represent the magnitude of variation in the correlation coefficients along growing degree days (GDD $>5^{\circ} \mathrm{C}$ ) and different elevations. To analyze the growth response of $P$. roxburghii to climatic factors a multi linear mixed model was practiced, given below:

$$
\mathrm{W}_{\mathrm{ij}}=\beta_{0}+\beta_{1} \mathrm{x}_{\mathrm{ij}}+\mu_{\mathrm{i} 1}+\mu_{\mathrm{i} 2} \mathrm{x}_{\mathrm{ij}}+\varepsilon_{\mathrm{ij}}
$$

where $\mathrm{W}_{\mathrm{ij}}$ and $\mathrm{x}_{\mathrm{ij}}$ denotes the tree ring chronologies and climatic factors for year $\mathrm{i}$ and site $\mathrm{j} ; \mu_{\mathrm{i} 1}$ and $\mu_{\mathrm{i} 2}$ are the intercept and slope values; $\beta 0$ and $\beta 1$ are the stable effects; $\varepsilon_{\mathrm{ij}}$ are site errors, $\mu_{\mathrm{i} 1}, \mu_{\mathrm{i} 2}$ and $\varepsilon i j$ are assumed to be independent. The parameters of linear mixed model were estimated (Bates et al., 2014) using the Matlab software (ver. R2017a, MathWorks Inc., USA).

\section{Results}

\section{Variation in climatic factors}

Seasonal variation in major climatic variables air temperature and precipitation were shown in Fig. 2. The long term (1995-2015) minimum, maximum, and mean air temperature from 1995-2015 were close to zero in winters and reached to seasonal maximum values during mid-summer period and peaked in June or July (Fig. 2a). The precipitation presented a clear seasonal trend generally varied with timing and amount (Fig. 2b). Winter and early springs were usually with little precipitation and the time period between July and August received most of the annual rainfall.

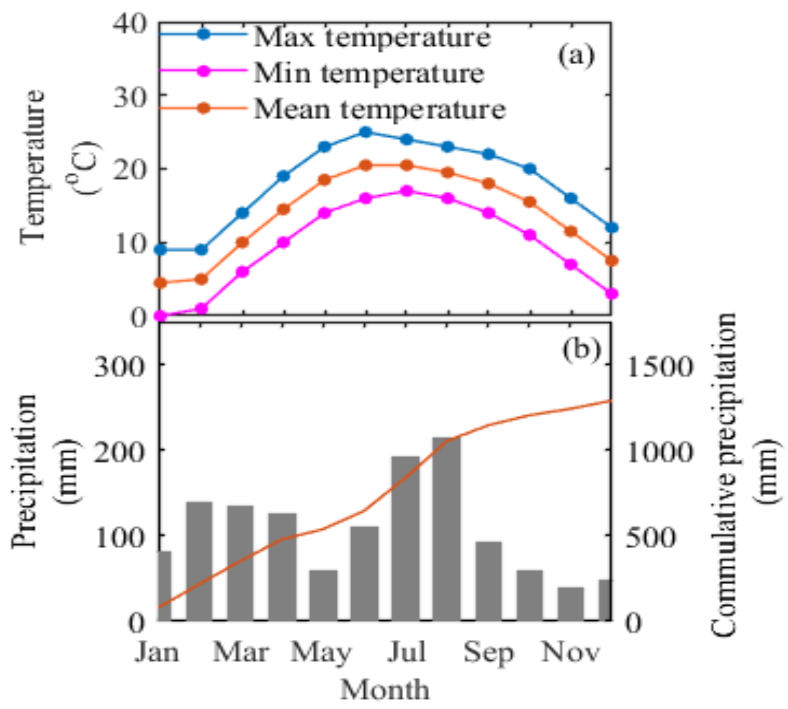

Figure 2. Seasonal variation in (a) monthly mean minimum and maximum temperature (b) total monthly precipitation and cumulative precipitation during 1995-2015 
Long term variation in temperature and precipitation during the 20-year period were shown in Fig. 3. The annual maximum and minimum temperature ranged between $25.2-27.8^{\circ} \mathrm{C}$ and $12.8-14.7^{\circ} \mathrm{C}$ during $1995-2015$. The variation in mean temperature was evident to be almost similar to the minimum temperature. The annual mean temperature was highest as $21.0^{\circ} \mathrm{C}$, and lowest as $19.2^{\circ} \mathrm{C}$, during 1999 and 1995 , respectively (Fig. 3b). In addition, the slope pattern representing minimum and mean air temperature was steeper in comparison to the maximum temperature. The inter-annual mean values during 1995-2015 were $26.5 \pm 0.57,13.4 \pm 0.39$ and $20.90 \pm 0.37^{\circ} \mathrm{C}$ for maximum, minimum and mean temperature respectively (Fig. 3a,b, Table 1). The variation was observed greater in minimum than maximum and mean temperatures with coefficient of variation $2.8,2.01$ and $1.85 \%$, respectively. The inter-annual variation in annual total precipitation depicts an overall increasing trend whereas it varied markedly between 20 years (Fig. 3b). A great variation range between 590.8-1650 mm yr ${ }^{-1}$ was evident in the study area. The highest precipitation received in 2006 and lowest in 2000. Generally, the time period during 1999-2000 received lowest annual precipitation (Fig. 3b). The twentyyear inter-annual mean value of precipitation was $1190.7 \pm 257.48 \mathrm{~mm}$ with $21 \%$ coefficient of variation (Table 1).

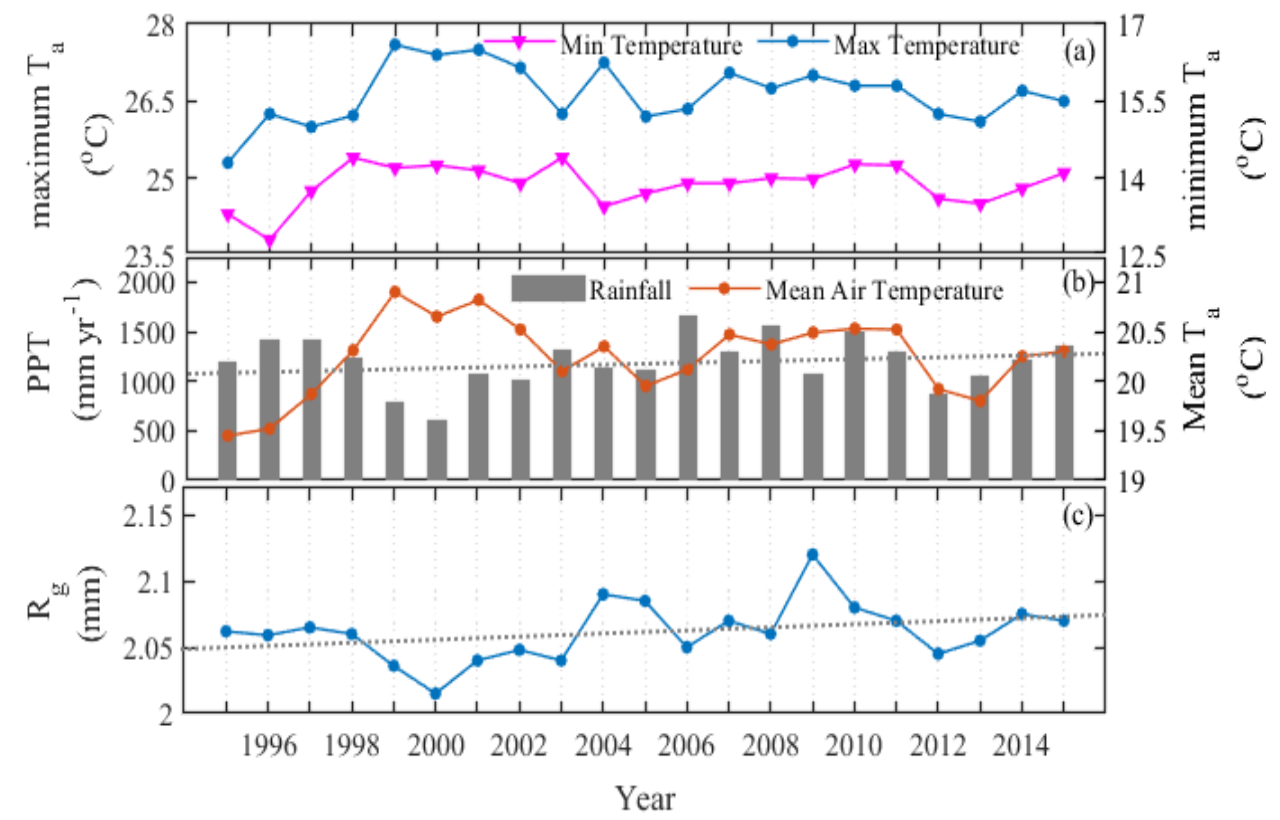

Figure 3. Temporal variation in (a) maximum and minimum air temperature (b) precipitation and mean air temperature $(c)$ tree radial growth $\left(R_{g}\right)$ of $P$. roxburghii from 1995-2015. The dotted lines in $b$ and $c$ represents degree of slope

Table 1. Inter-annual variability in maximum, minimum, mean air temperature and total Precipitation over 1995-2015

\begin{tabular}{c|c|c|c|c}
\hline Variables & \multicolumn{3}{|c|}{ Temperature } & Precipitation \\
\hline & Max & Min & Mean & Mean \\
\hline 20 years average & 26.5 & 13.4 & 20.90 & 1190.7 \\
Standard deviation & 0.57 & 0.39 & 0.37 & 257.48 \\
Coefficient of variation (\%) & 2.8 & 2.01 & 1.85 & 21 \\
\hline
\end{tabular}




\section{Statistical parameters of $\boldsymbol{R}_{g}$}

The constructed chronologies based on $48 P$. roxburghii radial growth ring-series (each point was average of three replicates at one site) followed a time span length ranged between 33-91 years (Table 2). The two oldest trees had 104 rings. The maximum tree radial growth $\left(\mathrm{R}_{\mathrm{g}}\right)$ was observed in 2004, 2009, and $2014(2.065,2.12$, and $2.07 \mathrm{~mm}$, respectively) while the smallest or depressed radial growth was $2.01 \mathrm{~mm}$ in 2000 and $2.04 \mathrm{~mm}$ in 2012 (Fig. 3c). The inter-annual mean $\mathrm{R}_{\mathrm{g}}$ was $2.06 \mathrm{~mm}( \pm 0.022)$ with $1.06 \%$ coefficient of variation during 1995-2015, which constitute both early and late wood formation (Fig. 3c). The annual sensitivity (slope) of the $\mathrm{R}_{\mathrm{g}}$ was 0.19 . Moreover, the years showing no ring formation (missing ring) or fused rings were few since last 20 years and there were no absent rings in last 10 years. Contrary an insignificant rise of $0.05 \mathrm{~mm}$ in ring widths was observed.

Table 2. Relative information of the site variables and standard chronologies of P. roxburghii. Elev. and std. stands for elevation and standard deviation, respectively

\begin{tabular}{c|c|c|c|c|c|c|c|c|c}
\hline Site & Elev. & $\begin{array}{c}\text { Radial } \\
\text { growth }\end{array}$ & Std. & Age & Site & Elev. & $\begin{array}{c}\text { Radial } \\
\text { growth }\end{array}$ & Std. & Age \\
\hline No. & $(\mathbf{m})$ & $(\mathbf{m m})$ & $(\mathbf{m m})$ & $(\mathbf{Y r})$. & No. & $(\mathbf{m})$ & $(\mathbf{m m})$ & $(\mathbf{m m})$ & $($ Yr. $)$ \\
\hline T1 & 1840 & 2.5 & 0.406 & 80 & T 25 & 1380 & 2.8 & 0.32 & 73 \\
T 2 & 1800 & 2 & 0.65 & 60 & T 26 & 1360 & 2.6 & 0.286 & 78 \\
T 3 & 1750 & 2.25 & 0.536 & 75 & T 27 & 1340 & 3 & 0.392 & 66 \\
T 4 & 1790 & 2.5 & 0.71 & 36 & T 28 & 1320 & 2.7 & 0.554 & 64 \\
T 5 & 1780 & 2.25 & 0.174 & 47 & T 29 & 1300 & 2.7 & 0.144 & 56 \\
T 6 & 1700 & 2.5 & 0.39 & 60 & T 30 & 1280 & 2.25 & 0.315 & 53 \\
T 7 & 1720 & 2.25 & 0.51 & 44 & T 31 & 1260 & 2 & 0.25 & 61 \\
T 8 & 1720 & 2.5 & 0.393 & 72 & T 32 & 1240 & 2.75 & 0.55 & 65 \\
T 9 & 1600 & 2.75 & 0.401 & 69 & T 33 & 1220 & 2.75 & 0.174 & 58 \\
T 10 & 1620 & 2 & 0.54 & 58 & T 34 & 1200 & 2.25 & 0.35 & 47 \\
T 11 & 1550 & 2.75 & 0.311 & 91 & T 35 & 1180 & 2 & 0.25 & 48 \\
T 12 & 1640 & 2.75 & 0.363 & 77 & T 36 & 1160 & 2.3 & 0.047 & 59 \\
T 13 & 1610 & 2.5 & 0.585 & 66 & T 37 & 1140 & 2.9 & 0.233 & 59 \\
T 14 & 1500 & 2.75 & 0.439 & 66 & T 38 & 1130 & 2.6 & 0.266 & 55 \\
T 15 & 1400 & 2.75 & 0.257 & 72 & T 39 & 1120 & 2.75 & 0.161 & 74 \\
T 16 & 1560 & 2 & 0.392 & 54 & T 40 & 1100 & 2.3 & 0.4 & 75 \\
T 17 & 1480 & 2.3 & 0.554 & 64 & T 41 & 1090 & 2.4 & 0.021 & 55 \\
T 18 & 1520 & 2.7 & 0.693 & 50 & T 42 & 1080 & 2.7 & 0.286 & 62 \\
T 19 & 1500 & 2.5 & 0.8 & 61 & T 43 & 1070 & 2.5 & 0.392 & 67 \\
T 20 & 1480 & 2.9 & 0.576 & 78 & T 44 & 1050 & 2.3 & 0.554 & 71 \\
T 21 & 1460 & 2.4 & 0.45 & 41 & T 45 & 1030 & 2.5 & 0.144 & 74 \\
T 22 & 1440 & 3.1 & 0.619 & 55 & T 46 & 1020 & 1.9 & 0.315 & 82 \\
T 23 & 1420 & 3.3 & 0.35 & 63 & T 47 & 1000 & 2.55 & 0.25 & 69 \\
T 24 & 1400 & 2.4 & 0.508 & 65 & T 48 & 980 & 2.2 & 0.052 & 56 \\
\hline
\end{tabular}




\section{Long-term climate-growth relationship}

Fig. $3 c$ revealed that inter annual variation in $\mathrm{R}_{\mathrm{g}}$ clearly followed the variation pattern in precipitation and temperature, as clear rise in $R_{\mathrm{g}}$ was observed in 2004, 2005 and 2009 followed by moderate precipitation amount. Whereas significant depressions in $\mathrm{R}_{\mathrm{g}}$ during 2000, 2001 and 2012 were clearly related with low precipitation and high temperature. In contrast, the three largest precipitation years did not exhibit any significant rise in ring widths (Fig. 3b,c). In fact, the ring widths formation was lower than average, with year of extreme precipitation (such as 2006 and 2010). Subsequently our findings highlighted a baseline effect, below which the $\mathrm{R}_{\mathrm{g}}$ tend to be increased until attaining the baseline point. The $\mathrm{R}_{\mathrm{g}}$ showed no discernable trend above from baseline effect with further precipitation. Though, it appears that low $\mathrm{R}_{\mathrm{g}}(\sim 2.01 \mathrm{~mm})$ coincided with precipitation range between $690-900 \mathrm{~mm}$. The larger $\mathrm{R}_{\mathrm{g}}(2.1 \mathrm{~mm}$ and over) was supported by moderate precipitation levels of 950-1100 mm while large precipitation $1200 \mathrm{~mm}$ or above have adverse effects on annual growth (Fig. $3 b, c)$. The results therefore point out that moderate precipitation causing larger $\mathrm{R}_{\mathrm{g}}$, compared to smaller and larger precipitation events resulting in reduced growth. The results are further supported by regression analysis in Figure $4 a$.

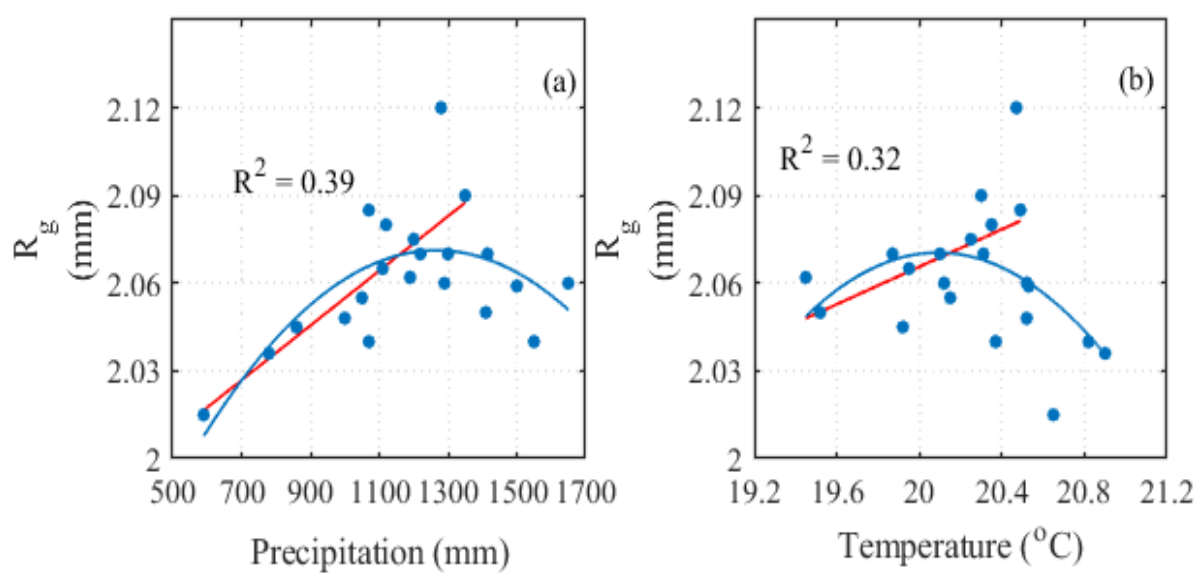

Figure 4. Relationships between radial growth and major climatic drivers (a) precipitation and (b) temperature. Solid red lines are linear and blue lines are quadratic fitting between radial growth increement and the relevant variables. Each data point represents is annual mean from 1995-2015

The tree $\mathrm{R}_{\mathrm{g}}$ less influenced by mean annual temperature than precipitation (Fig. 4a,b, Table 3; based on Eq.1). $\mathrm{R}_{\mathrm{g}}$ increased with increasing precipitation and temperature, then leveled off and gradually decreased showing 0.32 and 0.39 coefficient of determination respectively. Mean monthly precipitation and temperature also controls the $\mathrm{R}_{\mathrm{g}}$ (Fig. 5a-d). Correlation coefficient values revealed that previous year precipitation from June-August was especially important for tree $\mathrm{R}_{\mathrm{g}}(p<0.01$, Fig. $5 a)$ and the association progressively weakened $(p=0.05)$ and turned into negative from October-December. The $\mathrm{R}_{\mathrm{g}}$ often negatively correlated $(p<0.05$ ) with preceding summer temperature of May and August $\left(\mathrm{R}^{2}=-0.36\right.$ and -0.68 , respectively) and positively correlated with October and January $\left(\mathrm{R}^{2}=0.45 \mathrm{Fig}\right.$. $\left.5 \mathrm{~b}\right)$. In contrast, precipitation and temperature of current July showed strong positive control on $\mathrm{R}_{\mathrm{g}}(P<0.05$; Fig. $5 c$ and $d$, Table 3$)$. 
Table 3. Estimations of the response of radial ring-width of $P$. roxburghii to the total monthly precipitation, and mean monthly air temperature from May-Dec of preceding year and from Jan-Aug of current year by linear mixed models (Eq.1). One and two asterisk indicate $p<$ 0.05 , and $p<0.01$, respectively. $S E$ is the standard error

\begin{tabular}{|c|c|c|c|c|c|c|c|c|}
\hline \multirow[t]{2}{*}{ Variables } & \multicolumn{4}{|c|}{ Precipitation } & \multicolumn{4}{|c|}{ Temperature } \\
\hline & Month & Estimation & SE value & $t$ stats & Month & Estimation & SE value & $t$ stats \\
\hline \multirow{8}{*}{$\begin{array}{c}\text { Previous } \\
\text { year }\end{array}$} & May & $0.06^{*}$ & 0.026 & 3.19 & May & $-0.17 *$ & 0.024 & -2.15 \\
\hline & June & 0.13 & 0.025 & 1.362 & June & -0.85 & 0.021 & -1.05 \\
\hline & July & $0.22 * *$ & 0.026 & 4.53 & July & $-0.31 *$ & 0.021 & -2.42 \\
\hline & August & $0.37^{*}$ & 0.024 & 8.0 & August & $-0.22 *$ & 0.023 & -5.78 \\
\hline & September & $0.056^{*}$ & 0.024 & 3.64 & September & $-0.29 *$ & 0.023 & -2.81 \\
\hline & October & $-0.038^{*}$ & 0.025 & -2.24 & October & $0.48^{*}$ & 0.023 & 3.55 \\
\hline & November & 0.018 & 0.024 & 0.743 & November & 0.26 & 0.023 & 1.73 \\
\hline & December & -0.001 & 0.026 & -0.049 & December & $0.51 *$ & 0.023 & 2.65 \\
\hline \multirow{8}{*}{$\begin{array}{c}\text { Current } \\
\text { year }\end{array}$} & January & 0.043 & 0.027 & 0.62 & January & $0.10^{*}$ & 0.020 & 2.3 \\
\hline & February & 0.089 & 0.024 & 0.93 & February & -0.07 & 0.020 & -0.31 \\
\hline & March & -0.057 & 0.022 & -0.61 & March & $-0.19 *$ & 0.021 & -1.5 \\
\hline & April & -0.087 & 0.022 & -0.85 & April & $0.28 * *$ & 0.021 & 2.74 \\
\hline & May & 0.16 & $0.025^{*}$ & 4.80 & May & 0.32 & 0.021 & 0.87 \\
\hline & June & 0.247 & $0.022 *$ & 6.72 & June & $-0.097^{*}$ & 0.022 & -1.54 \\
\hline & July & 0.43 & $0.024 * *$ & 1.79 & July & $0.27 *$ & 0.023 & 2.95 \\
\hline & August & 0.068 & 0.023 & 2.77 & August & 0.085 & 0.021 & 2.63 \\
\hline
\end{tabular}

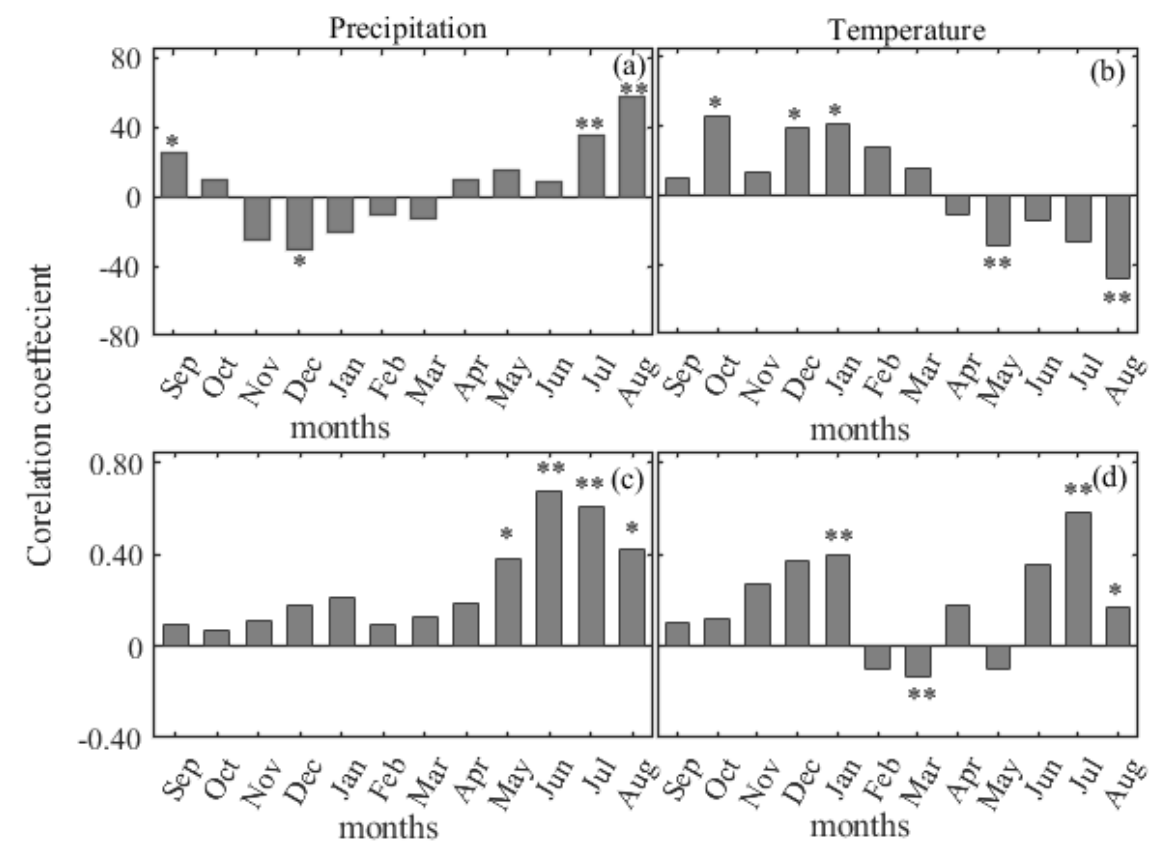

Figure 5. Bootstrap correlations coefficients calculated among radial growth of $P$. roxburghii and major climatic factors i.e., monthly total precipitation of (a) preceding year from May-Jan; (c) current year from Jan-Sep, and monthly mean temperature of $(b)$ preceding year from May-

Jan; (d) current year from Jan-Sep in 1995-2015. One and two asterisks (*,**) denotes significance level at 95 and $99 \%$ confidence $(p<0.05, p<0.01)$ respectively 


\section{Variation in climate-growth relationship along growing degree days $\left(G D D>5^{\circ} \mathrm{C}\right)$ and different elevations}

The coefficient of determination between $\mathrm{R}_{\mathrm{g}}$ at 48 sites and total monthly precipitation of current summer decreased with increasing elevation (Fig. 6a, $p<0.05$ ). In relation to elevation, $P$. roxburghii showed a robust dependency of $\mathrm{R}_{\mathrm{g}}$ to mean summer temperature. The significant positive relationships between $\mathrm{R}_{\mathrm{g}}$ and summer temperature was observed for higher elevations ( $>1300 \mathrm{~m}$ ), while below $\sim 1300 \mathrm{~m}$ the relationships became negative (Fig. 6b). The correlations of previous and current summer precipitation with radial growth showed similar increasing trend but slightly differed in magnitude at high GDDs (Fig. 6c, $p=0.018,0.025$, respectively). In comparison, with increasing GDD, the influence of current and preceding summer temperatures on trees radial growth progressively declined and became negative above $~ 900$ GDD (Fig. $6 d, p=0.041,0.039$, respectively).
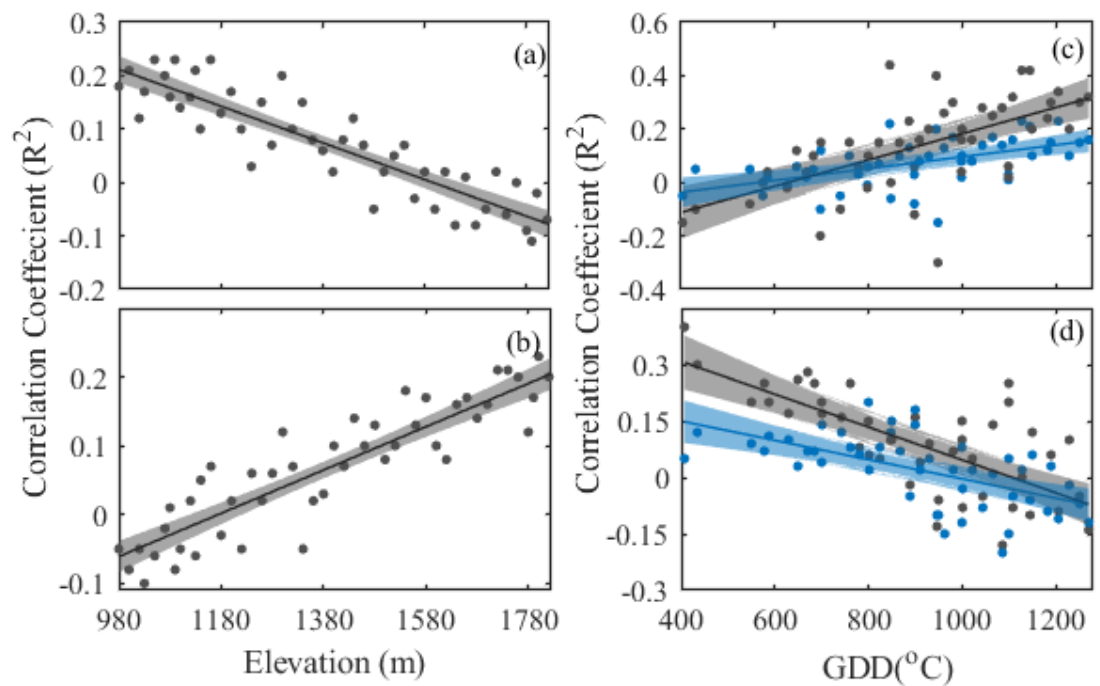

Figure 6. Variability in correlation coefficients of radial growth with (a) total monthly precipitation and (b) mean monthly temperature of current summer along increasing elevation;

(c) total monthly precipitation and (d) mean monthly temperature of preceding (blue) and current summer (grey); with growing degree days $\left(G D D>5{ }^{\circ} \mathrm{C}\right)$. The colored range shows $95 \%$ confidence level

The response curves in Fig. 7 showed radial growth responses to variation in temperature and soil moisture. Results indicated that radial growth affected by temperature were progressively increased and peaked its maximum in summer (July) and followed by zero effect in cold winter. Based on temperature and available soil water effected response curves, the $\mathrm{R}_{\mathrm{g}}$ in 28 sites were mainly controlled by available soil water contents associated with precipitation (e.g., SN. 3-6 in Fig. 7), 9 sites were limited by temperature (e.g., SN. 7, in Fig. 7), and 11 sites were not affected by both variables (e.g., SN. 1, 2, 8, in Fig. 7). Therefore, $48 \mathrm{R}_{\mathrm{g}}$ trends could be grouped into 3 categories i.e., trend I (was related to soil water controlled), trend II (temperature controlled), and trend III (not controlled by both). The radial growth and three patterns were all significant $(P<0.05)$. The response curves showed the growth of $P$. roxburghii was observed to be frequently controlled by soil moisture that is directly related to precipitation and fewer by temperature, though varied among different sites. 


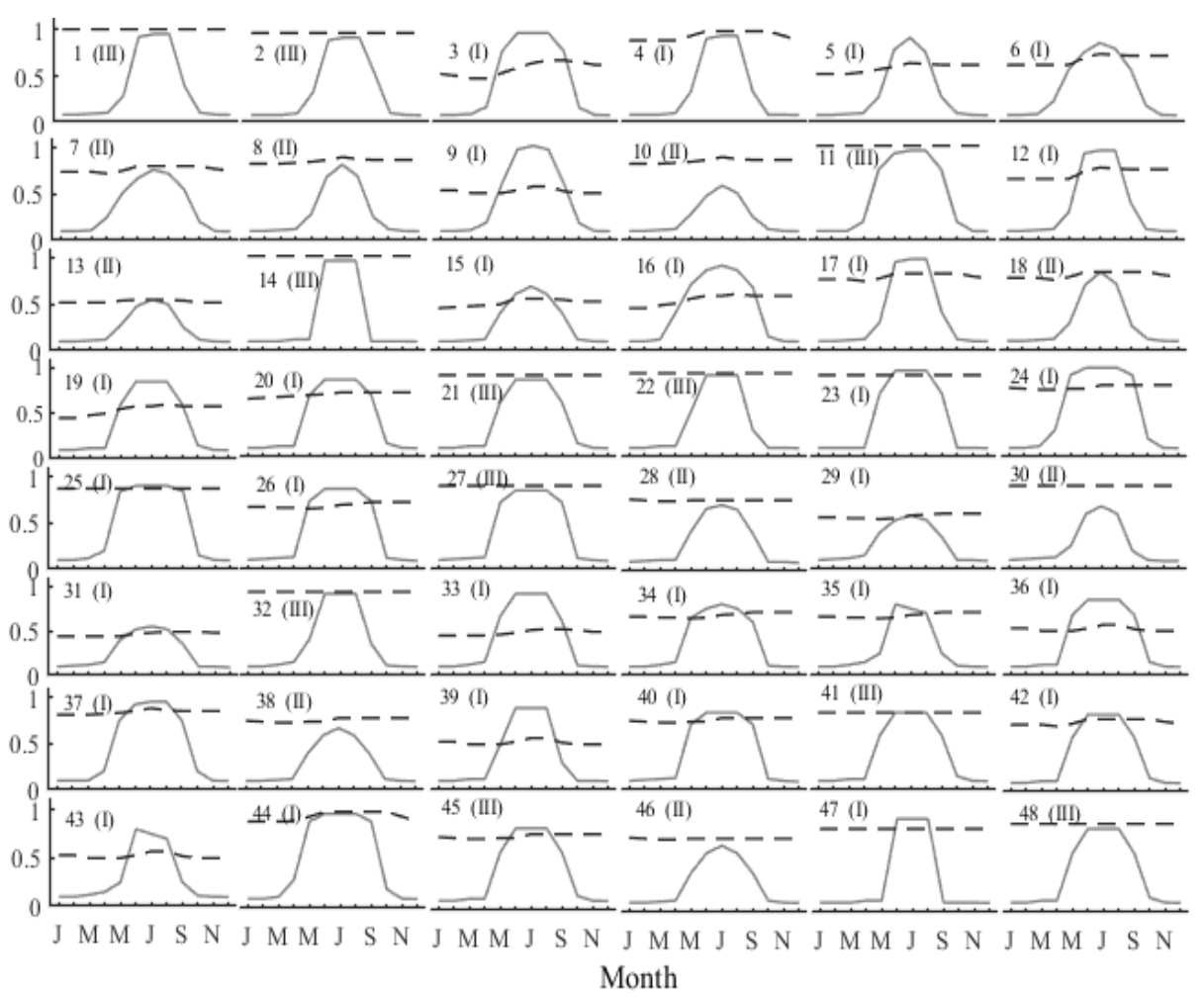

Figure 7. Seasonal variation showing by growth response curves of temperature (the solid) and moisture level (dashed lines). The label I represents moisture controlled, II temperature controlled and III does not controlled by any of two variables. Each response graph shows the growth pattern at each site $(n=48)$

\section{Discussions}

\section{Temporal variation in $R_{g}$ and its controlling mechanisms}

In comparison to global average temperature, the rise was observed by $0.74^{\circ} \mathrm{C}$ at local levels during 1906-2005 (IPCC, 2007). This study indicated that the mean maximum and minimum temperature increases with 0.60 and $1.27^{\circ} \mathrm{C}$, respectively, over long temporal scale (1995-2015). The results showed high variation in precipitation ranging between $590.8-1650 \mathrm{mmy}^{-1}$ with significant rise of $21 \%$ in study area (Fig. 3 b). The findings are in lined with previous results concluded by Grunewald et al. (2009) and Liu et al. (2010).

Previous research documented that several factors affect the tree radial growth characteristics, most of them are tree age and site specific related to management operations, however air temperature, precipitation and solar radiations were marked as broader climatic drivers (Yeh and Wensel, 2000). Our results showed that moderate precipitation range could produce larger ring growth and lower precipitation resulting smaller $\mathrm{R}_{\mathrm{g}}$ (Fig. 3c). These findings are in line with previous researches which suggests that the years producing narrow rings were mainly due to low precipitation levels (Bouriaud et al., 2004; Morecroft et al., 2008). Previous researches have demonstrated the similar effects of precipitation and temperature on radial growth and ring width characteristics. It has been found that the annual radial growth (diameter increment) was more often influenced by the effect of growing season precipitation and temperature and also months preceding that season in Pinus sylvestris, Abies alba, Picea abies, Picea sitchensis, Pseudotsuga menziesii (Feliksik and Wilczynski, 2009). According to Khan et 
al. (2013) radial growth of Cedrus deodara was found being a function of precipitation and temperature in Chitral-Hindukush, Pakistan.

Precipitation limits the growth rate of trees in many ecosystems more than temperature (Cherubini et al., 2003). However, the winter cold was key limiting factor mainly for tree species habitat in mountainous environment (Leburgeois et al., 2012; Martin-Benito et al., 2013) and for evergreen species (Granda et al., 2013). The regression results specified that the summer temperature of preceding year exerted high negative effect on $R_{\mathrm{g}}$ of $P$. roxburghii, whereas the temperature of preceding autumn and winter (Oct-Jan) had positive influence on the $\mathrm{R}_{\mathrm{g}}(\mathrm{p}<0.05$, Fig. $5 b)$. In summer season, when temperature increases to its maximum, the rate of evapotranspiration becomes high, which results in soil water shortages (Huang et al., 2010), thus become less responsive to temperature. The previous year temperature control was in lined to carryover effect explained by Fritts (2001) and Rammig et al. (2015) that, the deficient nutrient stored during preceding year marked a substantial influence on following year growth. Equally, high temperature in preceding year had inhibit the photosynthesis that impose a decline in growth formation of tree in the subsequent year owing to the inadequate carbohydrates storage. On the other hand, high autumn and winter temperatures favors the growth rate of following year (Fig. 5d) by increasing the size and subsistence of buds and thus, the acclimation ability of plant (Weber et al., 2007). Another reason might include, after dormant winter period, a warm end could gently accelerate the cambial reactivation and helps in earlier leaf out, which eventually prolong the period of wood formation (Sanz-Pérez et al., 2009; Viera et al., 2014).

The previous year precipitation showed positive and significant impacts on the $\mathrm{R}_{\mathrm{g}}$ (Fig. 5a). Preceding year precipitation is also important to boost radial growth formation in many species (Di Filippo et al., 2010). Soil water recharge during autumn and winter precipitation, when growth of $P$. roxburghii remain dormant, appears to be a vital element effecting tree growth rate in the subsequent growth season. This phenomenon found to be an indispensable reserve for commencement of cambial activity and early wood production (Granda et al., 2013; Martin-Benito et al., 2013). During current growing period, tree $\mathrm{R}_{\mathrm{g}}$ was more usual positive relationship with May and June precipitation (Fig. 5c) and revealed a negative correlation with temperature (Fig. 5d). Sufficient precipitation could positively effect on radial growth through making an improvement in xylem cell production and lessen the water stress in an area (Deslauriers et al., 2016). Consequently, this phenomenon favors the positive response of radial growth to precipitation in both preceding and present growing season.

Inclusively, these findings suggest that precipitation and temperature of previous and current growing seasons are the primary controlling factors for growth rate of Chir pine. Prior to the commencement of cold in winter, the species might complete photosynthesis process to stock energy thus execute a positive influence on the tree $\mathrm{R}_{\mathrm{g}}$ similar to various evergreen conifers (Miyazawa and Kikuzawa, 2005). Consequently, the temperature of previous year October-December was positively correlated with $\mathrm{R}_{\mathrm{g}}$ (Table 3, Fig. 5b). Previous studies showed the strong effect of previous summer climate variables on radial growth (Teets et al., 2018).

\section{Spatial variation in the climate growth relationship with GDDs}

Results specified that the $\mathrm{R}_{\mathrm{g}}$ in $P$. roxburghii was more probably to down regulated by warmer summer temperature which suggests a higher dependency of tree $\mathrm{R}_{\mathrm{g}}$ to summer temperature in context of elevation gradient (Fig. 6b). Over the past decades, the 
significant increasing trend in global temperature (IPCC, 2007) and $0.56-0.78^{\circ} \mathrm{C}$ in various forests of Pakistan was reported by Bukhari and Bajwa (2011). We also found that, warmer summers boosted the radial growth above $\sim 1300 \mathrm{~m}$ but reduced it below this elevation (Fig. 6b). A winter with warmer end might prevent the soft tissues of tree i.e., roots and buds damage by freezing stress, in higher altitudes (Miller-Rushing and Primack, 2008). Correlation analyses specified the variation in climate-growth relationships with increasing elevation (Huo et al., 2017). The relationship between $\mathrm{R}_{\mathrm{g}}$ and precipitation weakened with increasing elevation (Fig. $6 a$ ), due to the snow effect at higher elevation. A rise in precipitation can quickly reduce the environmental stress and stimulate the radial growth during water-deficit conditions at lower elevation and turn the relationship positive (Deslauriers et al., 2016). As a consequence, trees in the southern sites often grew in a dry and hot atmospheric conditions, so radial growth positively respond and being more sensitive to the increase of precipitation. Subsequently, the $R_{g}$ was limited by temperature owing to increasing GDD and decreasing precipitation (Fig. 6c,d). Similar findings have been observed for silver fir species decreasing at the southern edge, likely as a consequence of the cumulative influence of severe drought (Linares and Camarero, 2010). Moreover, white spruce in Western Canada has also been reported by similar variation (Chen et al., 2017).

The results specified the monthly variation in the response of radial growth to climatic variables i.e., temperature and soil moisture at fortyeight sites (Fig. 7). The response curves can detect the signals of temperature influencing or moisture limiting effect on radial growth of $P$. roxburghii in the subtropical pine forest. For instance, the radial growth was limited by soil moisture in 28 sites and few sites were limited by temperature. The eleven sites were similarly effected by temperature and moisture (Fig. 7). The nonsignificant effect in eleven sits suggested that the $\mathrm{R}_{\mathrm{g}}$ was neither restricted by precipitation nor by temperature, meanwhile could be influenced by some other site-specific factors (Gewehr et al., 2014). In addition, other site-specific factors such as micro environmental circumstances and species competition (Huang et al., 2013) may be crucial for tree growth determining at these pine sites.

\section{Conclusion}

Annual temperature and precipitation were the dominant limiting factor for the $\mathrm{R}_{\mathrm{g}}$ of $P$. roxburghii. Summer precipitation (June-August) of previous and current year was most important for tree $R_{g}$. The previous summer temperature imposed negative impact on $R_{g}$ while positive in current July. The $\mathrm{R}_{\mathrm{g}}$ was more often limited by soil moisture associated with lower precipitation and high temperature. The control of precipitation was seen to be more significant at lower elevation $(<1300 \mathrm{~m})$. However, $\mathrm{R}_{\mathrm{g}}$ showed clear dependency on summer temperature when elevation ranged above $1300 \mathrm{~m}$. The approaches employed in this study for unstable temporal responses and nonlinear dependency of $P$. roxburghii to climate drivers, are related to manage and predict the effects of a substantially varied landscape. It also has the potential to forecast future resource outcomes from these forested ecosystems and vulnerability of other forests by using a combination of processbased and global circulation models. In addition, tree sensitivity to site specific climatic variables might useful to expect climate change to decrease stand growth. Due to continuous increase in global climate change, it is suggested that continuous large scale measurements are required to address the temperature and moisture induced variation in climate-growth analysis for sustainable forest management. 
Acknowledgments. The study was supported by National Natural Science Foundation of China (NSFC) (31361130340, 31270755), and Fundamental Research Funds for the Central Universities (2015ZCQ-SB02), a project of USCCC University of Eastern Finland, and Academy of Finland (proj. No. 14921). This research is also allied to the continuing Finnish-Chinese research collaboration project EXTREME, among University of Eastern Finland (UEF) and Beijing Forestry University (BJFU). We are thankful to Yuan Li and Mingyan Zhang for their support with the measurements and well maintenance of laboratory instruments.

Conflicts of Interest. The authors declare no conflict of interest.

\section{REFERENCES}

[1] Allen, C. D., Macalady, A. K., Chenchouni, H., Bachelet, D., McDowell, N. (2010): A global overview of drought and heat-induced tree mortality reveals emerging climate change risks for forests. - Forest Ecology and Management 259: 660-684.

[2] Altman, J., Fibich, P., Santruckova, H., Dolezal, J., Stepanek, P., Kopacek, J., Hunova, I., Oulehle, F., Tumajer, J., Cienciala, E. (2017): Environmental factors exert strong control over the climate-growth relationships of Picea abies in Central Europe. - Science of the Total Environment 609: 506-516.

[3] Bates, D., Maechler, M., Bolker, B., Walker, S. (2014): LME4: Linear mixed-effects models using Eigen and S4. - R package version 1(7): 1-23.

[4] Bednarz, Z., Ptak, J. (1990): The influence of temperature and precipitation on ring widths of oak (Quercus robur L) in the Niepolomice forest near cracow, southern Poland. - TreeRing Bulletin 50(1): 1-9.

[5] Bouriaud, O., Bréda, N., Moguéder, G., Nepveu, G. (2004): Modelling variability of wood density in beech as affected by ring age, radial growth and climate. - Trees: Structure \& Function 18(3): 264-276.

[6] Briffa, K. R., Osborn, T. J., Schweingruber, F. H., Jones, P. D., Shiyatov, S. G., Vaganov, E. A. (2002): Tree-ring width and density data around the Northern Hemisphere: part 2, spatio-temporal variability and associated climate patterns. - Holocene 12: 759-78.

[7] Bukhari, S. S. B., Bajwa, G. A. (2011): Climate change trends over coniferous forests of Pakistan. - Pakistan Journal of Forestry 61: 1-14.

[8] Bunn, A. G. (2008): A dendrochronology program library in R (dplR). Dendrochronologia 26(2): 115-124.

[9] Chen, L., Huanga, J.-G., Stadt, K. J., Comeaud, P. G., Zhai, L., Dawsone, A., Alam, S. A. (2017): Drought explains variation in the radial growth of white spruce in western Canada. - Agricultural and Forest Meteorology 233: 133-142.

[10] Cherubini, P., Gartner, B. L., Tognetti, R., Braker, O. U., Schoch, W., Innes, J. L. (2003): Identifcation, measurement and interpretation of tree rings in woody species from mediterranean climates. - Biological Reviews 78: 119-148.

[11] Cook, E. R., Esper, J., D’Arrigo, R. D. (2004): Extra-tropical Northern Hemisphere land temperature variability over the past 1000 years. - Quatenary Science Reviews 23(20): 2063-2074.

[12] D'Arrigo, R., Wilson, R., Liepert, B., Cherubini, P. (2008): On the 'divergence problem' in northern forests: a review of the tree-ring evidence and possible causes. - Global and Planetary Change 60(3): 289-305.

[13] Deslauriers, A., Huang, J. G., Balducci, L., Beaulieu, M., Rossi, S. (2016): The contribution of carbon and water in modulating wood formation in black spruce saplings. - Plant Physiology 170(4): 2072-2084.

[14] Di Filippo, A., Alessandrini, A., Biondi, F., Blasi, S., Portoghesi, L., Piovesan, G. (2010): Climate change and oak growth decline: dendroecology and stand productivity of a Turkey oak (Quercus cerris L.) old stored coppice in Central Italy. - Annals of Forest Science 67: 706. 
[15] Drew, D. M., Allen, K., Downes, G. M., Evans, R., Battaglia, M., Baker, P. (2013): Wood properties in a long-lived conifer reveal strong climate signals where ring-width series do not. - Tree Physiology 33: 37-47.

[16] Esper, J., Cook, E. R., Schweingruber, F. H. (2002): Low-frequency signals in long treering chronologies for reconstructing past temperature variability. - Science 295: 22502253.

[17] Fekedulegn, D., Hicks Jr, R. R., Colbert, J. J. (2003): Influence of topographic aspect, precipitation and drought on radial growth of four major tree species in an Appalachian watershed. - Forest Ecology and Management 6094: 1-17.

[18] Feliksik, E., Wilczynski, S. (2009): The effect of climate on tree-ring chronologies of native and nonnative tree species growing under homogenous site conditions. - Geochronometria 33: 49-57.

[19] Flannigan, M. D., Krawchuk, M. A., de Groot, W. J., Wotton, B. M., Gowman, L. M. (2009): Implications of changing climate for global wildland fire. - International Journal of Wildland Fire 18: 483-507.

[20] Fritts, H. (2001): Tree Rings and Climate. - The Blackburn Press, Caldwell.

[21] Gewehr, S., Drobyshev, I., Berninger, F., Bergeron, Y. (2014): Soil characteristics mediate the distribution and response of boreal trees to climatic variability. - Canadian Journal of Forest Research 44(5): 487-498.

[22] Ghazoul, J., Burivalova, Z., Garcia-Ulloa, J., King, L. A. (2015): Conceptualizing forest degradation. - Trends in Ecology and Evolution 30: 622-32.

[23] Granda, E., Camarero, J. J., Gimeno, T. E., Martínez-Fernández, J., Valladares, F. (2013): Intensity and timing of warming and drought differentially affect growth patterns of cooccurring Mediterranean tree species. - European Journal of Forest Research 132: 469480.

[24] Grunewald, K., Scheithauer, J., Monget, J. M., Brown, D. (2009): Characterisation of contemporary local climate change in the mountains of southwest Bulgaria. - Climate Change 95: 535-549.

[25] Holmes, R. L. (1983): Computer-assisted quality control in tree-ring dating and measurement. - Tree-Ring Bull. 43: 69-78.

[26] Holmes, R. L., Adams, R. K., Fritts, H. C. (1986): Tree-ring chronologies of western North America: California, eastern Oregon and northern Great Basin. - Laboratory of Tree-Ring Research, University of Arizona, Tucson.

[27] Huang, J., Tardif, J. C., Bergeron, Y., Denneler, B., Berninger, F., Girardin, M. P. (2010): Radial growth response of four dominant boreal tree species to climate along a latitudinal gradient in the eastern Canadian boreal forest. - Global Change Biology 16: 711-731.

[28] Huang, J. G., Stadt, K. J., Dawson, A., Comeau, P. G. (2013): Modelling growthcompetition relationships in trembling aspen and white spruce mixed boreal forests of Western Canada. - PLoS One 8(10): e77607.

[29] Hughes, M. K., Swetnam, T. W., Diaz, H. F. (2010): Dendroclimatology: Progress and Prospects. - Springer Science \& Business Media.

[30] Huo, Y., Gou, X., Liu, W., Li, J., Zhang, F., Fang, K. (2017): Climate-growth relationships of Schrenk spruce (Picea schrenkiana) along an altitudinal gradient in the western Tianshan mountains, northwest China. - Trees 31(2): 429-439.

[31] IPCC. (2007): Synthesis report: Contribution of working groups I, II and III to the fourth assessment report of the intergovernmental panel on climate change. - IPCC, Geneva, Switzerland, pp: 1-104.

[32] IPCC. (2014): Synthesis Report: Contribution of Working Groups I, II and III to the Fifth Assessment Report of the Intergovernmental Panel on Climate Change. - In: Pachauri, R. K., Meyer, L. A. (eds.) Core Writing Team. IPCC, Geneva, Switzerland, 151p.

[33] Jones, P. D., Briffa, K. R., Osborn, T. J., Lough, J. M., Van Ommen, T. D., Vinther, B. M., Xoplaki, E. (2009): High-resolution palaeoclimatology of the last millennium: a review of current status and future prospects. - Holocene 19(1): 3-49. 
[34] Kasischke, E. S., Stocks, B. J. (eds.) (2012): Fire, Climate Change, and Carbon Cycling in the Boreal Forest. - Springer Science \& Business Media 138.

[35] Khan, N., Ahmed, M., Shaukat, S. S. (2013): Climatic signal in tree-ring chronologies of Cedrus deodara from Chitral Hindukush range of Pakistan. - Pakistan Journal of Botany 40: 195-207.

[36] Kottek, M., Grieser, J., Beck, C., Rudolf, B., Rubel, F. (2006): World Map of the KöppenGeiger climate classification updated. - Meteorologische Zeitschrift 15: 259-263.

[37] Leburgeois, F., Mérian, P., Courdier, F., Ladier, J., Dreyfus, P. (2012): Instability of climate signal in tree-ring width in Mediterranean mountains: a multi-species analysis. Trees 26: 715-729.

[38] Lemoine, D., Peltier, J. P., Marigo, G. (2001): Comparative studies of the water relations and the hydraulic characteristics in Fraxinus excelsior, Acer pseudoplatanus and A. opalus trees under soil water contrasted conditions. - Annals of Forest Science 58(7): 723-731.

[39] Linares, J. C., Camarero, J. J., Carreira, J. A. (2010): Competition modulates the adaptation capacity of forests to climatic stress: insights from recent growth decline and death in relict stands of the Mediterranean fir Abies pinsapo. - Journal of Ecology 98: 592-603.

[40] Liu, B., Henderson, H., Zhang, Y., Xu, M. (2010): Spatiotemporal change in China's climatic growing season: 1955-2000. - Climate Change 99: 93-118.

[41] Lloyd, A. H., Duffy, P. A., Mann, D. H. (2013): Nonlinear responses of white spruce growth to climate variability in interior Alaska. - Canadian Journal of Forest Research 43(999): 331-343.

[42] Ma, Z., Peng, C., Zhu, Q., Chen, H., Yu, G., Li, W., Zhou, X., Wang, W., Zhang, W. (2012): Regional drought-induced reduction in the biomass carbon sink of Canada's boreal forests. - Proceedings of the National Academy of Sciences U. S. A. 109(7): 2423-2427.

[43] Martin-Benito, D., Beeckman, H., Canellas, I. (2013): Influence of drought on tree ring sand tracheid features of Pinus nigra and Pinus sylvestris in a mesic Mediterranean forest. - Europian Journal of Forest Research 132: 33-45.

[44] Maxime, C., Hendrik, D. (2011): Effects of climate on diameter growth of co-occurring Fagus sylvatica and Abies alba along an altitudinal gradient. - Trees 25(2): 265-276.

[45] McCullough, D. G., Werner, R. A., Neumann, D. (1998): Fire and insects in northern and boreal forest ecosystems of North America. - Annual Review of Entomology 43: 107-127.

[46] Miller-Rushing, A. J., Primack, R. B. (2008): Effects of winter temperatures on two birch (Betula) species. - Tree Physiology 28(4): 659-664.

[47] Miyazawa, Y., Kikuzawa, K. (2005): Winter photosynthesis by saplings of evergreen broad-leaved trees in a deciduous temperate forest. - New Phytology 165(3): 857-866.

[48] Morecroft, M. D., Stokes, V. J., Taylor, M. E., Morison, J. I. L. (2008): Effects of climate and management history on the distribution and growth of sycamore (Acer pseudoplatanus L.) in a southern British woodland in comparison to native competitors. - Forestry 81(1): 59-74.

[49] Nizami, S. M. (2012): The inventory of the carbon stocks in sub-tropical forests of Pakistan for reporting under Kyoto Protocol. - Journal of Forestry Research 23(3): 377-384.

[50] Olano, J. M., Eugenio, M., García-Cervigón, A. I., Folch, M., Rozas, V. (2012): Quantitative tracheid anatomy reveals a complex environmental control of wood structure in continental Mediterranean climate. - International Journal of Plant Sciences 173: 137149.

[51] Pilcher, J. R., Gray, B. (1982): The relationships between oak tree growth and climate in Britain. - Journal of Ecology 70(1): 297-304.

[52] Porter, T. J., Pisaric, M. F. (2011): Temperature-growth divergence in white spruce forests of Old Crow Flats, Yukon territory, and adjacent regions of northwestern North America. - Global Change Biology 17(11): 3418-3430.

[53] Price, D. T., Alfaro, R. I., Brown, K. J., Flannigan, M. D., Fleming, R. A., Hogg, E. H., Girardin, M. P., Lakusta, T., Johnston, M., McKenney, D. W., Pedlar, J. H. (2013): 
Anticipating the consequences of climate change for Canada's boreal forest ecosystems. Environmental Reviews 21(4): 322-365.

[54] Rammig, A., Wiedermann, M., Donges, J. F., Babst, F., von Bloh, W., Frank, D., Thonicke, K., Mahecha, M. D. (2015): Coincidences of climate extremes and anomalous vegetation responses: comparing tree ring patterns to simulated productivity. - Biogeosciences 12(2): 373-385.

[55] Saeed, S., Ashraf, M. I., Ahmad, A. (2016): The Bela forest ecosystem of district Jhelum, a potential carbon sink. - Pakistan Journal of Botany 48(1): 121-129.

[56] Sanz-Perez, V., Castro-Diez, P., Valladares, F. (2009): Differential and interactive effects of temperature and photoperiod on budburst and carbon reserves in two co-occurring Mediterranean oaks. - Plant Biology 11: 142-151.

[57] Schweingruber, F. G. (1996): Tree rings and environment. - Dendroecology. Haupt, Bern, Switzerland.

[58] Seidl, R., Schelhaas, M. J., Rammer, W., Verkerk, P. J. (2014): Increasing forest disturbances in Europe and their impact on carbon storage. - Nature Climate Change 4: 806-10.

[59] Sheikh, M. I. (1993): Trees of Pakistan. - Pictoral Printers, Islamabad, Pakistan.

[60] Speer, J. H. (2010): Fundamentals of Tree-ring Research. - University of Arizona Press.

[61] Teets, A., Fraver, S., Weiskittel, A. R., Hollinger, D. Y. (2018): Quantifying climategrowth relationships at the stand level in a mature mixed-species conifer forest. - Global change biology 24(8): 3587-3602.

[62] Tissier, J., Lambs, L., Peltier, J. P., Marigo, G. (2004): Relationships between hydraulic traits and habitat preference for six Acer species occurring in the French Alps. - Annals of Forest Science 61(1): 81-86.

[63] Tolwinski-Ward, S. E., Evans, M. N., Hughes, M. K., Anchukaitis, K. J. (2011): An efficient forward model of the climate controls on interannual variation in tree-ring width. - Climate Dynamics 36(11-12): 2419-2439.

[64] Turner, M. G. (2010): Disturbance and landscape dynamics in a changing world. - Ecology 91: 2833-2849.

[65] Valladares, F., Benavides, R., Rabasa, S. G., Diaz, M., Pausas, J. G., Paula, S., Simonson, W. D. (2014): Global change and Mediterranean forests: current impacts and potential responses. - Forests and Global Change, pp: 47-75.

[66] Viera, J., Rossi, S., Campelo, F., Freitas, H., Nabais, C. (2014): Xylogenesis of Pinus pinaster under a Mediterranean climate. - Annals of Forest Science 71: 71-80.

[67] Visser, H., Büntgen, U., D’Arrigo, R., Petersen, A. (2010): Detecting instabilities in treering proxy calibration. - Climate of the Past 6(3): 367-377.

[68] Weber, P., Bugmann, H., Rigling, A. (2007): Radial growth responses to drought of Pinus sylvestris and Quercus pubescens in an inner Alpine dry valley. - Journal of Vegetation Science 18: 777-792.

[69] Yeh, H. Y., Wensel, L. C. (2000): The relationship between tree diameter growth and climate for coniferous species in northern California. - Canadian Journal of Forest Research 30: 1463-1471.

[70] Zang, C., Hartl-Meier, C., Dittmar, C., Rothe, A., Menzel, A. (2014): Patterns of drought tolerance in major European temperate forest trees: climatic drivers and levels of variability. - Global Change Biology 20: 3767-3779.

[71] Zhang, Y., Wilmking, M. (2010): Divergent growth responses and increasing temperature limitation of Qinghai spruce growth along an elevation gradient at the northeast Tibet Plateau. - Forest Ecology and Management 260(6): 1076-1082. 